\title{
FAKTOR-FAKTOR YANG MEMPENGARUHI PETANI DALAM PENERAPAN BENIH PADI VARIETAS CIHERANG DI DESA PUDAK KECAMATAN KUMPEH ULU
}

\author{
Ratnawaty Siata \\ Staf Pengajar Jurusan Agribisnis Fakultas Pertanian Universitas Jambi \\ E-mail: Alsasyafira@yahoo.com
}

\begin{abstract}
ABSTRAK. Penelitian ini dilaksanakan bertujuan untuk mengetahui faktor-faktor yang mempengaruhi petani dalam penerapan benih padi varietas ciherang di Desa Pudak Kecamatan Kumpeh Ulu. Penelitian ini dilaksanakan pada bulan Agustus 2015 sampai dengan bulan September 2015. Metode analisis yang digunakan pada penelitian ini adalah metode analisis regresi logistik biner. Hasil penelitian ini mengungkapkan bahwa faktor selera petani, produksi, luas lahan dan kesesuaian lahan memiliki kecenderungan berpengaruh yang sangat signifikan dan berpengaruh nyata terhadap tinggi rendahnya peluang petani dalam melakukan penerapan benih padi varietas ciherang. Peluang petani menerapkan benih padi varietas ciherang karena selera petani sebesar $71 \%$. Sebaliknya peluang petani yang menerapkan benih padi varietas ciherang bukan karena selera petani sebesar $29 \%$. Peluang petani menerapkan benih padi varietas ciherang karena produksi sebesar $52 \%$. Sebaliknya peluang petani yang menerapkan benih padi varietas ciherang bukan karena produksi sebesar $48 \%$. Peluang petani menerapkan benih padi varietas ciherang karena luas lahan sebesar $58 \%$. Sebaliknya peluang petani yang menerapkan benih padi varietas ciherang bukan karena luas lahan sebesar $42 \%$ dan Peluang petani menerapkan benih padi varietas ciherang karena kesesuaian lahan sebesar $78 \%$. Sebaliknya peluang petani yang menerapkan benih padi varietas ciherang bukan karena kesesuaian lahan sebesar $22 \%$.
\end{abstract}

Kata kunci: Kesesuaian Lahan, Luas Lahan, Produksi, Selera dan Varietas Ciherang.

\section{AFFECTING FARMERS IN THE APPLICATION OF RICE SEED VARIETIES CIHERANG RURAL DISTRICTS KASANG PUDAK KUMPEH ULU JAMBI}

\begin{abstract}
This research aims to know the factors that affect farmers in the application of rice seed ciherang variety in Pudak village Kumpeh Ulu District. This Research was held in August 2015 until September 2015. The method of anylisis data is a logistic binary regression. Based on the results of the analysis showed that the taste factor of farmers, production, land area and land suitability has a tendency to influence a very significant and real on the high and low chances of farmers in the application of rice seed ciherang variety. Opportunities farmers applying rice seed ciherang variety for taste farmers by $71 \%$. Instead odds farmers who apply rice seed ciherang variety were not for taste farmers by $29 \%$. Opportunities farmers applying rice seed ciherang variety for the production of $52 \%$. Instead odds farmers who apply rice seed ciherang variety not because of production by 48\%. Opportunities farmers applying rice seed ciherang variety because the land area by 58\%. Instead odds farmers who apply rice seed ciherang variety not because the land area by $42 \%$ and Opportunities of farmers applying rice seed ciherang variety for suitability of land by 78\%. Instead odds farmers who apply rice seed ciherang variety were not for the suitability of land by $22 \%$.
\end{abstract}

Key word: Land suitability, Land Area, Production, tastes and Ciherang Variety.

\section{PENDAHULUAN}

Sektor pertanian dalam pembangunan nasional memegang peranan penting karena bertujuan menyediakan pangan bagi seluruh penduduk dan merupakan sektor andalan penyumbang devisa negara. Salah satu subsektor pertanian yang menjadi prioritas untuk dikembangkan secara terus menerus adalah tanaman pangan. Komoditi tanaman pangan yang banyak diusahakan petani sebagai penyuplai pangan nasional adalah tanaman padi. Padi merupakan salah satu bahan pangan nasional yang telah menjadi makanan pokok sebagian besar penduduk Indonesia (Budianto, 2002 dalam Mika Jayanti, 2011).

Di Provinsi Jambi salah satu Kabupaten yang cukup banyak menopang produksi padi adalah Kabupaten Muaro Jambi dengan total luas panen $10.894 \mathrm{Ha}$, produksi 50.929 ton dan produktivitas $46,75 \mathrm{kw} / \mathrm{Ha}$. Upaya untuk meningkatkan produksi dan produktivitas usahatani padi terus dilakukan oleh pemerintah agar keamanan pangan, pendapatan dan kesejahteraan petani terus meningkat. Peningkatan produksi dan produktivitas padi yang dicapai selama ini karena adanya penggunaan benih padi varietas unggul dan semakin membaiknya mutu usahatani seperti pengolahan tanah, cara tanam dan pemupukan. Hal ini tidak terlepas dari kemampuan petani dalam menerapkan teknologi pertanian secara efektif dan penyuluh pertanian bertindak sebagai jembatan dan sekaligus penghantar teknologi. Pembaharuan teknologi tersebut bertujuan untuk memberikan kemudahan didalam proses pertanian. Penemuanpenemuan teknologi ini kemudian dilakukan usahausaha untuk mensosialisasikannya kepada para petani. Proses sosialisasi biasanya dilakukan oleh PPL sebagai pihak yang menjembatani pemerintah sebagai pembuat kebijakan serta para peneliti yang menemukan inovasiinovasi tersebut (Mubyarto, 1985 dalam Mika Jayanti, 2011). 
Teknologi yang dimaksud adalah benih yang dapat meningkatkan hasil lebih tinggi dan bermutu baik yaitu benih bersertifikat. Benih merupakan sarana produksi yang sangat penting dalam meningkatkan produktivitas suatu tanaman, sedangkan sarana produksi lainnya seperti pupuk dan pestisida hanya akan memberikan dukungan yang positif, apabila disertai dengan peng-gunaan benih bermutu. Keuntungan menggunakan benih bermutu dibandingkan dengan benih lokal yaitu benih bermutu (berlabel) telah memenuhi syarat dan dijamin oleh pemerintah. Benih bermutu mempunyai kemurnian tinggi, sehingga memberikan kepuasan tersendiri bagi petani, pertanaman yang dihasilkan tumbuh serempak maka akan memudahkan pemanenan. Benih menjadi salah satu faktor utama yang menjadi penentu keberhasilan. Penggunaan benih unggul dapat menaikkan daya hasil $15 \%$ dibandingkan dengan penggunaan benih yang tidak bersertifikat (Santoso, 2005 dalam David Fahmi, 2008).

Pemerintah melalui Dinas Pertanian memberikan bantuan benih padi bersubsidi kepada para petani untuk mewujudkan peningkatan produksi tanaman padi melalui penyebaran benih padi varietas unggul. Penyebaran benih padi varietas unggul tertinggi di Kabupaten Muaro Jambi adalah Kecamatan Kumpeh Ulu yaitu varietas unggul ciherang. Desa Pudak merupa-kan Desa yang menerapkan benih padi varietas ciherang tertinggi diantara 10 Desa lainnya yang berusahatani padi sawah di Kecamatan Kumpeh Ulu yaitu sebesar $4.125 \mathrm{Kg}$ dengan luas tanam 185 Ha. Pada penerapannya terdapat petani yang menerapkan benih padi varietas ciherang dan terdapat petani yang tidak menerapkan benih padi varietas ciherang yaitu dengan menerapkan varietas lain. Petani yang menerapkan benih padi varietas ciherang di Desa pudak sebanyak 154 petani dengan luas tanam sebesar 150 Ha sedangkan petani yang tidak menerapkan benih padi varietas ciherang sebanyak 34 petani dengan luas tanam 35 Ha. Petani yang tidak menerapkan benih varietas ciherang tersebut menerapkan benih padi varietas lain dan benih padi lokal .

Penerapan benih padi varietas ciherang salah satunya dipengaruhi oleh faktor selera petani terhadap benih yang dihasilkan dengan rasa nasi yang dihasilkan. Rasa nasi yang dihasilkan oleh benih ciherang merupakan selera yang disukai oleh petani. Benih padi varietas ciherang menghasilkan nasi dengan jenis pulen, bersih dan tidak berbau. Benih padi yang dihasilkan menjadi salah satu hal yang penting dalam suatu penerapan karena mempengaruhi selera petani. Selera merupakan pilihan suka atau tidak suka seseorang terhadap produk (barang atau jasa) yang di konsumsi sesuai yang diinginkan. Semakin tinggi selera konsumen terhadap suatu barang, semakin banyak barang yang diminta (Kotler, 2000). Hasil produksi yang dihasilkan oleh petani Desa Pudak sebagian besar untuk dikonsumsi oleh petani sehingga rasa nasi yang diinginkan petani untuk dikonsumsi mempengaruhi petani dalam penerapan sehingga faktor selera mempengaruhi petani dalam penerapan benih padi varietas ciherang.

Faktor lain yang mempengaruhi petani dalam pene-rapan benih padi varietas ciherang adalah faktor produksi. Usahatani padi sawah di Desa Pudak selama 5 tahun terakhir terus mengalami peningkatan. Semakin tinggiproduksiyang dihasilkan petani dalammenerapkan benih padi varietas unggul ciherang maka semakin tinggi keinginan petani untuk menerapkannya. Pada penerapan benih padi varietas ciherang faktor luas lahan yang dimiliki petani juga mempengaruhi petani dalam menerapkan dan tidak menerapkan benih padi varietas ciherang, karena semakin luas lahan yang dimiliki petani maka semakin besar keinginan petani untuk mengadopsi teknologi seperti benih unggul varietas ciherang untuk dapat meningkatkan usahataninya. Usahatani padi sawah pada pertumbuhannya harus pada lahan yang sesuai untuk dapat tumbuh dengan baik. Kesesuaian lahan ditentukan oleh kecocokan sifat fisik lingkungan, iklim, tanah, lereng, dan topografi pada suatu wilayah. Benih padi yang di tanam di lahan yang sesuai akan tumbuh, berkembang dan berbuah dengan baik sedangkan benih padi yang ditanam namun tidak sesuai dengan lahan yang dibutuhkan tanaman maka benih akan tumbuh dan berkembang dengan tidak baik sehingga kesesuaian lahan juga sangat mempengaruhi petani dalam penerapan benih padi varietas ciherang.

Kesesuaian lahan dilihat antara sifat fisik lingkungan dari suatu wilayah dengan persyaratan penggunaan atau komoditas yang dievaluasi memberikan gambaran atau informasi bahwa lahan tersebut potensial dikembangkan untuk komoditas tersebut. Benih padi yang di tanam di lahan yang sesuai akan tumbuh, berkembang dan berbuah dengan baik namun jika benih padi yang ditanam tidak sesuai dengan lahan yang dibutuhkan tanaman maka benih tidak akan tumbuh dan berkembang dengan baik. Hal ini mempunyai pengertian bahwa jika lahan tersebut digunakan untuk penggunaan tertentu dengan mempertimbangkan berbagai asumsi mencakup masukan (input) yang diperlukan akan mampu memberikan hasil (output) sesuai dengan yang diharapkan (Djaenuddin dkk, 2000 dalam suyoko, 2008).

Berdasarkan uraian diatas, maka penulis tertarik melaksanakan penelitian dengan judul "Faktor-Faktor yang Mempengaruhi Petani dalam Penerapan Benih Padi Varietas Ciherang di Desa Pudak Kecamatan Kumpeh Ulu." Penelitian ini dilakukan dengan tujuan untuk mengetahui faktor-faktor apa saja yang dapat mempengaruhi petani dalam penerapan benih padi varietas ciherang di Desa Pudak Kecamatan Kumpeh Ulu. 


\section{METODE}

Penelitian ini dilaksanakan di Desa Pudak Kecamatan Kumpeh Ulu. Pemilihan daerah penelitian ini diambil dengan sengaja dengan pertimbangan bahwa lokasi tersebut merupakan salah satu daerah pengembangan usahatani padi sawah dengan penerapan benih padi varietas ciherang tertinggi di Kecamatan Kumpeh Ulu. Penelitian ini dilaksanakan pada tanggal 06 Agustus 2015 sampai dengan tanggal 06 September 2015. Teknik pengambilan sampelnya menggunakan rumus dari Taro Tamane atau Slovin (Riduwan, 2007) sebagai berikut:

$$
\mathrm{n}=\frac{\mathrm{N}}{\mathrm{Nd}^{2}+1}
$$

Dimana : $\mathrm{n}$

$$
\begin{aligned}
& =\text { Jumlah sampel } \\
& =\text { Jumlah populasi } \\
& =\text { Presisi (ditetapkan 10\%) }
\end{aligned}
$$

Pengambilan sampel dengan rumus ini berguna untuk menambah tingkat ketelitian dalam penelitian ini. Dari perhitungan sampel dengan menggunakan rumus diatas, maka diperoleh sampel sebanyak 61 responden untuk sampel petani yang menerapkan benih padi varietas ciherang sedangkan pengambilan sampel untuk petani yang tidak menerapkan benih padi varietas ciherang dilakukan secara sensus. Hal tersebut karena jumlah sampel yang terbatas sehingga petani yang tidak menerapkan benih padi varietas ciherang di Desa Pudak seluruhnya dijadikan sampel yaitu sebanyak 34 responden.Untuk lebih jelasnya populasi dan jumlah petani sampel di daerah penelitian dapat dilihat pada tabel 1 .

Tabel 1. Populasi Petani dan Jumlah Petani Sampel di Daerah Penelitian Desa Pudak Kecamatan Kumpeh Ulu.

\begin{tabular}{clcc}
\hline No & $\begin{array}{c}\text { Petani Sampel yang } \\
\text { Melakukan Penerapan } \\
\text { Benih Padi Varietas } \\
\text { Ciherang }\end{array}$ & $\begin{array}{c}\text { Populasi } \\
\text { (Orang) }\end{array}$ & $\begin{array}{c}\text { Sampel } \\
\text { (Orang) }\end{array}$ \\
\hline 1 & Petani yang menerapkan & 154 & 61 \\
2 & $\begin{array}{l}\text { Petani yang tidak } \\
\text { menerapkan }\end{array}$ & 34 & 34 \\
\hline & Total/Jumlah & 188 & 95 \\
\hline
\end{tabular}

Metode analisis yang digunakan pada penelitian ini untuk menganalisis faktor-faktor yang mempengaruhi petani dalam penerapan benih padi varietas ciherang adalah menggunakan model regresi logistik biner (Binary Logistic) yang dikenal juga dengan model logit. Regresi logistik disebut model regresi respon dikotomis dengan variabel dependen (penerapan) bernilai 0 dan 1 dimana dalam penelitian ini :

$\mathrm{Y}=1$; Apabila petani menerapkan benih padi varietas ciherang

$\mathrm{Y}=0$; Apabila petani tidak apabila petani menerapkan benih padi varietas ciherang
Model awal persamaan regresi logistik dalam penelitian ini adalah :

$$
P\left(x_{i}\right)=\frac{1}{1+e^{\beta_{0}+\beta_{1} x_{1}+\beta_{2} x_{2}+\beta_{8} x_{8}+\beta_{2} x_{4}+\beta_{5} x_{5}}}
$$

Model diatas merupakan model probabilitas suatu kejadian yang dipengaruhi oleh faktor-faktor Persamaan ini bersifat nonlinear dalam parameter. Selanjutnya untuk menjadikan model tersebut linear, proses transformasi yang dinamakan logit transformer perlu dilakukan:

$$
\begin{aligned}
& \operatorname{Ln}\left(\frac{P\left(x_{i}\right)}{1-P\left(x_{i}\right)}\right)=\beta_{0}+\beta_{1} X_{1}+\beta_{2} X_{2}+\beta_{3} X_{3}+\beta_{4} X_{4} \\
& Z_{i}=\beta_{0}+\beta_{1} X_{1}+\beta_{2} X_{2}+\beta_{3} X_{3}+\beta_{4} X_{4}
\end{aligned}
$$

Aplikasi model diatas untuk penelitian ini adalah sebagai berikut :

Regresi logistik disebut model regresi respon dikotomis dengan variabel dependen (penerapan) bernilai 0 dan 1 dimana dalam penelitian ini :

$\mathrm{Y}=1$; Apabila petani menerapkan benih padi varietas ciherang

$\mathrm{Y}=0$; Apabila petani tidak apabila petani menerapkan benih padi varietas ciherang

Model awal persamaan regresi logistik dalam penelitian ini adalah:

$$
P\left(x_{i}\right)=\frac{1}{1+e^{\beta_{0}+\beta_{1} x_{1}+\beta_{2} x_{2}+\beta_{g} x_{9}+\beta_{4} x_{4}}}
$$

Model diatas merupakan model probabilitas suatu kejadian yang dipengaruhi oleh faktor-faktor Persamaan ini bersifat nonlinear dalam parameter. Selanjutnya untuk menjadikan model tersebut linear, proses transformasi yang dinamakan logit transformer perlu dilakukan.

Aplikasi model diatas untuk penelitian ini adalah sebagai berikut :

$$
\begin{aligned}
& \operatorname{Ln}\left(\frac{P\left(x_{i}\right)}{1-P\left(x_{i}\right)}\right)=\beta_{0}+\beta_{1} X_{1}+\beta_{2} X_{2}+\beta_{3} X_{3}+\beta_{4} X_{4} \\
& Z_{i}=\beta_{0}+\beta_{1} X_{1}+\beta_{2} X_{2}+\beta_{3} X_{3}+\beta_{4} X_{4} \\
& \mathbf{Y}=\mathbf{b o}+\mathbf{b}_{1} \mathbf{X}_{1}+\mathbf{b}_{2} \mathbf{X}_{2}+\mathbf{b}_{3} \mathbf{X}_{3}+\mathbf{b}_{4} \mathbf{X}_{4}+\mathbf{d} \mathbf{X}_{4.1}+\mathbf{d} \mathbf{X}_{4.2} \\
& +\mathbf{d} \mathbf{X}_{5.1+} \mathbf{d} \mathbf{X}_{5.2}
\end{aligned}
$$

Dimana :

$\mathrm{y}=1$ : Menerapkan benih padi varietas ciherang

$\mathrm{y}=0$ : Tidak menerapkan benih padi varietas ciherang $\mathrm{x}_{1}=$ Selera $($ suka $=1 ;$ tidak suka $=0)$

$\mathrm{x}_{2}=$ Produksi (Ton)

$\mathrm{x}_{3}=$ Luas lahan $(\mathrm{Ha})$

$\mathrm{x}_{4}=$ Kesesuaian Lahan $($ sesuai $=1$; tidak sesuai $=0$ )

$\mathrm{dx}_{4.1}=$ Pengaruh kesesuaian lahan dengan lahan yang sesuai terhadap penerapan benih varietas ciherang

$\mathrm{dx}_{4.2}=$ Pengaruh kesesuaian lahan dengan lahan yang tidak sesuai terhadap penerapan benih varietas ciherang 
$\mathrm{dx}_{51}=$ Pengaruh selera dengan rasa suka nasi terhadap penerapan benih varietas ciherang

$\mathrm{dx}_{5.2}=$ Pengaruh selera dengan rasa tidak suka rasa nasi terhadap penerapan benih varietas ciherang

Pada regresi binary logistic untuk mengukur seberapa besar variasi dari variabel dependennya dapat dijelaskan oleh variasi nilai variabel-variabel independennya digunakan Koefisien determinasi. Nilai pada koefisien determinasi digunakan untuk mengetahu kecocokan (goodness of fit) dari model yang digunakan. Koefisien determinasi dapat dilihat dari nilai $\mathrm{R}^{2}$ dan adjusted $\mathrm{R}^{2}$. Penggunaan adjusted $\mathrm{R}^{2}$ sebagai acuan untuk melihat nilai koefisien determinasi berlaku untuk regresi dengan lebih dari dua variabel bebas (Gujarati, 2003). Pada regresi binary logistic nilai $\mathrm{R}^{2}$ dilihat dari nilai $R$ Square yang ada didalam output EVIEWS.

Nilai $R^{2}$ memiliki rentang nilai antara 0 sampai 1 . Jika nilai $\mathrm{R}^{2}$ sama dengan 0 , maka tidak ada sedikitpun presentase sumbangan pengaruh yang diberikan variabel independen terhadap variabel dependen, atau variasi variabel independen yang digunakan dalam model tidak menjelaskan sedikitpun variasi variabel dependen. Sebaliknya jika nilai $\mathrm{R}^{2}$ sama dengan 1 , maka presentase sumbangan pengaruh yang diberikan variabel independen terhadap variabel dependen adalah sempurna, atau variasi variabel independen yang digunakan dalam model menjelaskan $100 \%$ variasi variabel dependen.

\section{Uji Signifikansi dari Parameter}

Pada umumnya, uji ini dilakukan setelah uji signifikansi model memutuskan bahwa minimal ada satu variabel bebas yang memiliki pengaruh signifikan terhadap variabel tak bebas. Uji signifikansi parameter dilakukan untuk mengetahui pengaruh masing-masing variabel-variabel independen terhadap variabel dependen sehingga diketahui variabel independen yang signifikan mempengaruhi variabel dependen.

Kriteria hipotesisnya adalah sebagai berikut :

$\mathrm{H}_{0}:=0$ (Variabel independen ke i tidak berpengaruh signifikan terhadap variabel dependen)

$\mathrm{H}_{1}: \neq 0$ (Variabel independen ke $\mathrm{i}$ berpengaruh signifikan terhadap variabel dependen)

Nilai Z pada persamaan diatas bila dikuadratkan maka menghasilkan nilai statistika Wald yang mengikuti distribusi chi-square. Jika nilai statistika Wald lebih besar daripada nilai chi square pada tabel maka $\mathrm{H}_{0}$ ditolak yang berarti variabel independen berpengaruh signifikan pada variabel dependen. Jika nilai statistika Wald lebih kecil daripada nilai chi square pada tabel maka $\mathrm{H}_{0}$ yang berarti variable independen tidak berpengaruh signifikan pada variable dependen. Pengambilan keputusan hipotesis juga dapat dilihat dengan melihat nilai probabilitasnya (p-value). Gujarati (2003) menyatakan bahwa jika nilai p-value lebih kecil dari nilai alpha $(\alpha)$ maka dengan tingkat keyakinan (1- $\alpha$ ) hipotesis Ho ditolak.

2. Nilai Odds Ratio

Odds ratio merupakan ukuran risiko atau kecenderungan untuk mengalami kejadian tertentu antara satu kategori dengan kategori lainnya, didefinisikan sebagai ratio dari odds untuk $=1$ terhadap $=0$. Nilai odds ratio digunakan untuk menginterpretasikan hubungan antara variabel independen dengan variabel dependen yang memiliki perbedaan dengan regresi linear berganda dengan variabel tidak bebas berbentuk kontinyu (kuantitatif). Pada regresi logistik koefisien dari modelnya tidak bisa serta merta diinterpretasikan langsung atau nilai dari koefisien disini tidak mempunyai arti praktis yang layak (Gujarati, 2006). Odds suatu penerapan benih padi varietas ciherang merupakan :

P (1) = probabilitas petani menerapkan benih padi varietas ciherang

$\mathrm{P}(0)=$ probabilitas petani tidak menerapkan benih padi varietas ciherang

\section{HASIL DAN PEMBAHASAN}

\section{Gambaran Usahatani Padi Sawah Desa Pudak}

Desa Pudak mayoritas masyarakatnya menggantungkan kehidupan ekonominya dari usahatani padi sawah. Lahan sawah yang digunakan untuk melakukan kegiatan ushatani merupakan lahan tadah hujan. Potensi lahan tadah hujan sebesar $650 \mathrm{Ha}$ namun hanya $350 \mathrm{Ha}$ yang sudah terbuka dan 185 Ha yang ditanami termasuk 50 Ha merupakan penangkaran benih. Penangkaran benih di Desa Pudak sudah dimulai sejak tahun 2008 dan sampai saat ini terus berkembang dengan indeks pertanaman 300 atau 3 kali tanam dalam setahun.

Penangkaran benih dilakukan oleh Kelompok tani usaha sepakat. 4 kelompok tani lainnya yang masih aktif antara lain kelompok tani Sri Rezeki, Rengas Gumpung, Jaya Bersama dengan indeks pertanaman 200 atau 2 kali tanam dalam setahun dan kelompok tani Gelintang Tani dengan indeks pertanaman 100 atau 1 kali tanam dalam setahun. Wilayah lahan sawah kelompok tani gelintang tani berada di dekat wilayah sungai Batanghari sehingga lebih sering terjadi banjir oleh sebab itu hanya melakukan satu kali tanam dalam setahun.

\section{Analisis Faktor-Faktor yang Mempengaruhi Petani dalam Penerapan Benih Padi Varietas Ciherang.}

Analisis logistik biner digunakan untuk menguji variabel independen atau variabel bebas yang dimasukkan ke dalam model. Tujuan dari analisis ini adalah untuk melihat apakah variabel independen seperti selera petani, produksi, luas lahan dan kesesuaian lahan mempengaruhi variabel dependen yaitu penerapan benih padi varietas ciherang untuk menerapkan atau tidak menerapkan benih 
padi varietas ciherang. Hasil dari analisis logistik biner adalah sebagai berikut:

\section{Uji Goodness of Fit}

Dari hasil analisis diketahui bahwa nilai R Square adalah sebesar 0,678. Hal ini menunjukkan bahwa perubahan variabel-variabel bebas atau variabel independen yang dimasukkan ke dalam model dapat menjelaskan perubahan variabel tak bebas atau variabel dependen sebesar $67,8 \%$. Sedangkan sisanya yaitu sebesar $32,2 \%$ dijelaskan oleh variabel lain yang tidak dijelaskan di dalam model.

\section{Uji Signifikan dari Parameter}

Berdasarkan hasil analisis dapat diketahui bahwa variabel dengan nilai yang lebih kecil dari signifikansi 0,05 adalah selera petani, produksi, luas lahan dan kesesuaian lahan. Nilai signifikansi dari masingmasing variabel tersebut adalah variabel $\mathrm{X}_{1}$ yaitu selera petani merupakan variabel dummy $(1=$ suka ; $0=$ tidak suka) dengan nilai signifikansi $\mathrm{X}_{4,1}$ sebesar 0,000 dan $X_{4.2}$ sebesar 0,008 . Variabel $X_{2}$ yaitu produksi dengan nilai signifikansi sebesar 0,002, variabel X3 yaitu luas lahan dengan nilai signifikansi sebesar 0,004 dan variabel X4 yaitu kesesuaian lahan merupakan variabel dummy $(1=$ sesuai ; $0=$ tidak sesuai) dengan nilai signifikansi X5.1 sebesar 0,05 dan X5.2 sebesar 0,06.

Hasil analisis faktor-faktor yang mempengaruhi petani dalam penerapan benih padi varietas ciherang untuk menerapkan atau tidak menerapkan benih padi varietas ciherang disajikan pada Tabel 2 .

Model Persamaan regresi logistik dalam penelitian ini ialah :

\section{$P\left(x_{i}\right)=\frac{1}{1+e^{-\left(\beta_{0}+\beta_{1} x_{1}+\beta_{2} x_{2}+\beta_{3} x_{18}+\beta_{4} x_{4}\right)}}$}

Maka berdasarkan tabel hasil analisis diperoleh persamaan regresi logistik terhadap faktor-faktor $\mathrm{X}_{1}, \mathrm{X}_{2}$, $\mathrm{X}_{3}$ dan $\mathrm{X}_{4}$ secara bersamasama adalah sebagai berikut :

$$
\begin{aligned}
& P\left(x_{i}\right)=\frac{1}{1+2,718^{-(-8,267+0,221(0,314)+2,875(0,003)-14,602(0,005)-0,088(0,711))}} \\
& P\left(x_{i}\right)=\frac{1}{1+2,718^{-(0,292)}} \\
& =0,57 \\
& =57 \%
\end{aligned}
$$

(Gujarati, 2006) Jika variabel independen secara bersamasama mempengaruhi dengan nilai peluang $40 \%$ sampai dengan $60 \%$ maka variabel independen secara bersamasama dalam model telah dianggap baik. Dalam penelitian ini secara bersama-sama $\mathrm{X}_{1}, \mathrm{X}_{2}, \mathrm{X}_{3}$ dan $\mathrm{X}_{4}$ mempengaruhi peluang petani menerapkan benih padi varietas ciherang adalah sebesar $57 \%$ maka variabel independennya dinyatakan dalam model adalah baik.

$\mathrm{X}=\frac{\text { Jumlah dari hasil faktor } \mathrm{X}}{\text { Jumlah Sampel }}$

Maka $\mathrm{X}$ dari masing-masing faktor $\mathrm{X}_{1}$ yaitu $\left(\mathrm{X}_{5.1}\right.$; $\left.\mathrm{X}_{5.2}\right), \mathrm{X}_{2}, \mathrm{X}_{3}$ dan $\mathrm{X}_{4}$ yaitu $\left(\mathrm{X}_{4.1} ; \mathrm{X}_{4.2)}\right.$ antara lain adalah sebagai berikut :

1. Faktor Selera Petani $\left(X_{1}\right)$ meliputi selera petani karena suka terhadap benih padi varietas ciherang $\left(\mathrm{X}_{5.1}\right)$ dan selera petani karena tidak suka terhadap benih gadi varietas ciherang $\left(\mathrm{X}_{5.2}\right)$

\begin{tabular}{|c|c|c|c|c|}
\hline Variable & Coefficient & Std. Error & z-Statistic & Prob. \\
\hline $\mathrm{X} 1$ & 0.220533 & 0.219012 & 1.006946 & 0.3140 \\
\hline $\mathrm{X} 2$ & 2.874927 & 0.964216 & 2.981622 & 0.0029 \\
\hline $\mathrm{X} 3$ & -14.60214 & 5.170329 & -2.824219 & 0.0047 \\
\hline $\mathrm{X} 4$ & -0.087912 & 0.236810 & -0.371235 & 0.7105 \\
\hline $\mathrm{X} 4 \_1$ & 5.657439 & 1.639068 & 3.451620 & 0.0006 \\
\hline $\mathrm{X} 4$ _2 & 3.171018 & 1.197172 & 2.648758 & 0.0081 \\
\hline X5_1 & 1.836186 & 0.946635 & 1.939697 & 0.0524 \\
\hline X5_2 & -2.149339 & 1.143127 & -1.880228 & 0.0601 \\
\hline $\mathrm{C}$ & -8.267944 & 2.741635 & -3.015699 & 0.0026 \\
\hline McFadden R-squared & 0.677568 & Mean dependent var & & 0.642105 \\
\hline S.D. dependent var & 0.481924 & S.E. of regression & & 0.264113 \\
\hline Akaike info criterion & 0.610052 & Sum squared resid & & 5.998967 \\
\hline Schwarz criterion & 0.851999 & Log likelihood & & -19.97748 \\
\hline Hannan-Quinn criter. & 0.707817 & Deviance & & 39.95497 \\
\hline Restr. deviance & 123.9175 & Restr. log likelihood & & -61.95874 \\
\hline LR statistic & 83.96251 & Avg. log likelihood & & -0.210289 \\
\hline Prob(LR statistic) & 0.000000 & & & \\
\hline Obs with Dep $=0$ & 34 & Total obs & & 95 \\
\hline Obs with Dep=1 & 61 & & & \\
\hline
\end{tabular}

$$
\begin{aligned}
& \bar{X}_{5.1}=\frac{65}{95}=0,71 \\
& \bar{X}_{5.2}=\frac{28}{95}=0,29
\end{aligned}
$$

Tabel 2. Analisis Regresi Binary Logistik Pada Faktor-Faktor yang Mempengaruhi Petani dalam Penerapan Benih Padi Varietas Ciherang di Daerah Penelitian Tahun 2015. 
2. Faktor Produksi $\left(\mathrm{X}_{2}\right)$

$\mathrm{X}_{2}=\frac{435,7}{95}=4,5$

3. Faktor Luas Lahan $\left(\mathrm{X}_{3}\right)$

$\overline{\mathrm{X}}_{3}=\frac{70,25}{95}=0,74$

4. Faktor Kesesuaian Lahan $\left(\mathrm{X}_{4}\right)$ meliputi kesesuaian lahan dengan lahan yang sesuai terhadap benih padi varietas ciherang $\left(\mathrm{X}_{41}\right)$ dan kesesuaian lahan dengan lahan yang tidak sesuai terhadap benih padi varietas ciherang $\left(\mathrm{X}_{4.2}\right)$

$$
\begin{aligned}
& \bar{X}_{4.1}=\frac{74}{95}=0,78 \\
& \bar{X}_{4.2}=\frac{21}{95}=0,2
\end{aligned}
$$

Berikut merupakan peluang yang menerapkan benih padi varietas ciherang terhadap faktor-faktor yang mempengaruhi petani dalam penerapan benih padi varietas ciherang secara parsial:

\section{Selera petani $\left(X_{P}\right)$}

Faktor selera petani berpengaruh sangat nyata terhadap keputusan petani untuk menerapkan benih padi varietas ciherang. Untuk melihat peluang petani yang menerapkan benih padi varietas ciherang terhadap faktor selera petani yang mempengaruhi penerapan benih padi varietas ciherang dapat dilihat pada tabel 3:

Tabel 3. Distribusi Responden Berdasarkan Faktor Selera Petani Tahun 2015

\begin{tabular}{cccc}
\hline \multirow{2}{*}{ Penerapan } & \multicolumn{3}{c}{ Selera petani } \\
\cline { 2 - 4 } & Tidak Suka & Suka & Jumlah \\
\hline $\begin{array}{c}\text { Menerapkan Benih } \\
\text { Ciherang }\end{array}$ & $7(11,5 \%)$ & $\begin{array}{c}54 \\
(88,5 \%)\end{array}$ & 61 \\
$\begin{array}{c}\text { Tidak Menerapkan Benih } \\
\text { Ciherang }\end{array}$ & $21(62 \%)$ & $\begin{array}{c}13 \\
(38 \%)\end{array}$ & 34 \\
Jumlah & $28(29 \%)$ & 67 & 95 \\
& & $(71 \%)$ & 95 \\
\hline
\end{tabular}

Sumber : Hasil Olahan Data Kuesioner 2015

Tabel 3 menjelaskan bahwa petani yang menerapkan benih padi varietas ciherang sebagai akibat selera petani terhadap rasa suka nasi yang dihasilkan oleh benih yaitu sebanyak 54 orang $(88,5 \%)$ sedangkan petani yang menerapkan benih padi varietas ciherang bukan karena selera petani terhadap benih yang dihasilkan sebanyak 7 orang (11,5\%). Maka peluang petani yang menerapkan benih padi varietas ciherang sebagai akibat selera petani terhadap rasa nasi yang dihasilkan oleh benih padi varietas ciherang sebesar $71 \%$. Sebaliknya peluang petani yang menerapkan benih padi varietas ciherang bukan karena selera petani terhadap rasa nasi yang dihasilkan oleh benih padi varietas ciherang adalah sebesar $29 \%$.

\section{Produksi $\left(\mathrm{X}_{2}\right)$}

Faktor produksi berpengaruh sangat nyata terhadap keputusan petani untuk menerapkan benih padi varietas ciherang. Untuk melihat peluang petani yang menerapkan benih padi varietas ciherang terhadap faktor produksi yang mempengaruhi penerapan benih padi varietas ciherang dapat dilihat pada tabel 4 :

Tabel 4. Distribusi Responden Berdasarkan Faktor Produksi Tahun 2015

\begin{tabular}{cccc}
\hline \multirow{2}{*}{ Penerapan } & \multicolumn{3}{c}{ Produksi $(\overline{\mathrm{Y}}=4.5$ Ton $)$} \\
\cline { 2 - 4 } & $\leq$ & $>$ & Jumlah \\
\hline $\begin{array}{c}\text { Menerapkan Benih } \\
\text { Ciherang }\end{array}$ & $\begin{array}{c}21 \\
(34,4 \%)\end{array}$ & $40(65,6 \%)$ & 61 \\
Tidak Menerapkan Benih & 25 & $9(26,5 \%)$ & 34 \\
\hline Ciherang & $(73,5)$ & $49(52 \%)$ & 95 \\
\hline Jumlah & $\begin{array}{c}46 \\
(48 \%)\end{array}$ & 490 \\
\hline
\end{tabular}

Sumber : Hasil Olahan Data Kuesioner 2015

Tabel 4 menjelaskan bahwa petani yang menerapkan benih padi varietas ciherang sebagai akibat produksi yang dihasilkan oleh benih yaitu sebanyak 40 orang $(65,6 \%)$ sedangkan petani yang menerapkan benih padi varietas ciherang bukan karena produksi terhadap benih yang dihasilkan sebanyak 21 orang (34,4 \%). Maka peluang petani yang menerapkan benih padi varietas ciherang sebagai akibat produksi yang dihasilkan oleh benih padi varietas ciherang sebesar $52 \%$. Sebaliknya peluang petani yang menerapkan benih padi varietas ciherang bukan karena produksi yang dihasilkan oleh benih padi varietas ciherang adalah sebesar $48 \%$.

\section{Luas Lahan $\left(\mathrm{X}_{3}\right)$}

Faktor luas lahan berpengaruh sangat nyata terhadap keputusan petani untuk menerapkan benih padi varietas ciherang. Untuk melihat peluang petani yang menerapkan benih padi varietas ciherang terhadap faktor luas lahan yang mempengaruhi penerapan benih padi varietas ciherang dapat dilihat pada tabel 5 : Tabel 5 menjelaskan bahwa petani yang menerapkan benih padi varietas ciherang sebagai akibat luas lahan yaitu sebanyak 42 orang (69\%) sedangkan petani yang menerapkan benih padi varietas ciherang bukan karena luas lahan sebanyak 19 orang (31\%). Maka peluang petani yang menerapkan benih padi varietas ciherang sebagai akibat luas lahan sebesar $58 \%$. Sebaliknya peluang petani yang menerapkan benih padi varietas ciherang bukan karena luas lahan adalah sebesar $42 \%$.

\section{Kesesuaian Lahan}

Faktor kesesuaian lahan berpengaruh sangat nyata terhadap keputusan petani untuk menerapkan benih padi varietas ciherang. Untuk melihat peluang petani yang menerapkan benih padi varietas ciherang terhadap faktor kesesuaian lahan berdasarkan sesuai dan tidak sesuai nya lahan dapat dilihat pada tabel 6 : 
Tabel 5. Distribusi Responden Berdasarkan Faktor Luas Lahan Tahun 2015

\begin{tabular}{cccc}
\hline \multirow{2}{*}{ Penerapan } & \multicolumn{3}{c}{ Luas Lahan $(\overline{\mathrm{Y}}=0.74 \mathrm{Ha})$} \\
\cline { 2 - 4 } & $\leq$ & $>$ & Jumlah \\
\hline $\begin{array}{c}\text { Menerapkan Benih } \\
\text { Ciherang }\end{array}$ & $19(31 \%)$ & $42(69)$ & 61 \\
$\begin{array}{c}\text { Tidak Menerapkan } \\
\text { Benih Ciherang }\end{array}$ & $21(61,8 \%)$ & $13(38,2 \%)$ & 34 \\
Jumlah & $40(42 \%)$ & $55(58 \%)$ & 95 \\
\hline & Sumber: Hasil Olahan Data Kuesioner 2015
\end{tabular}

Tabel 6. Distribusi Responden Berdasarkan Faktor Kesesuaian Lahan Tahun 2015

\begin{tabular}{cccc}
\hline \multirow{2}{*}{ Penerapan } & \multicolumn{3}{c}{ Kesesuaian Lahan } \\
\cline { 2 - 4 } & Sesuai & Sesuai & Jumlah \\
\hline $\begin{array}{c}\text { Menerapkan Benih } \\
\text { Ciherang }\end{array}$ & $2(3,3 \%)$ & $59(96,7 \%)$ & 61 \\
$\begin{array}{c}\text { Tidak Menerapkan } \\
\text { Benih Ciherang } \\
\text { Jumlah }\end{array}$ & $19(55,9 \%)$ & $15(44,1 \%)$ & 34 \\
\hline \multicolumn{4}{c}{ Sumber: Hasil Olahan Data Kuesioner 2015 }
\end{tabular}

Tabel 6 menjelaskan bahwa petani yang menerapkan benih padi varietas ciherang sebagai akibat kesesuaian lahan yang sesuai yaitu sebanyak 59 orang $(96,7$ \%) sedangkan petani yang menerapkan benih padi varietas ciherang bukan karena kesesuaian lahan yaitu tidak sesuai sebanyak 2 orang (3,3\%). Maka peluang petani yang menerapkan benih padi varietas ciherang sebagai akibat kesesuaian lahan sebesar $78 \%$. Sebaliknya peluang petani yang menerapkan benih padi varietas ciherang bukan karena kesesuaian lahan adalah sebesar $22 \%$.

\section{Nilai Oods Ratio}

Rasio peluang sebagai rasio perubahan oods suatu kejadian pada penerapan benih padi varietas ciherang adalah sebagai berikut :

$P\left(x_{i}\right)=e^{\beta_{i}}$

Pada masing-masing faktor untuk mengetahui perubahan peluang yang terjadi pada penerapan benih padi varietas ciherang dilakukan persamaan diatas.

\section{a. Selera Petani $\left(X_{1}\right)$}

Rasio peluang sebagai rasio perubahan suatu kejadian pada penerapan benih padi varietas ciherang terhadap faktor selera petani adalah :

$$
\begin{aligned}
& P\left(x_{i}\right)=e^{\beta_{i}} \\
& P\left(x_{i}\right)=e^{\beta_{i}} 2,718^{0,221}=1,25
\end{aligned}
$$

Maka dapat dijelaskan bahwa besarnya peluang petani menerapkan benih ciherang sebagai akibat dari selera petani adalah sebesar 1,25 kali.

Hal ini sejalan dengan penelitian yang dilakukan oleh Edi Suprapto (2010) yang menyatakan bahwa variabel selera petani mempunyai koefisien sebesar 0,106 dengan taraf signifikansi sebesar 0,003 dimana nilainya lebih kecil dari 0,05 . Artinya variabel selera petani mempunyai pengaruh positif dan signifikan secara statistik terhadap usahatani padi organik di Kabupaten Sragen. Dimana hal ini juga sesuai dengan landasan teoritis oleh Nuraini (2005) menyatakan bahwa selera masyarakat mempunyai pengaruh yang cukup besar terhadap keinginan masyarakat untuk membeli barang atau jasa. Jika selera konsumen terhadap suatu barang meningkat maka permintaan akan meningkat dan begitu pula sebaliknya jika selera konsumen terhadap suatu barang menurun maka permintaan akan menurun.

\section{b. Produksi $\left(\mathbf{X}_{2}\right)$}

Rasio peluang sebagai rasio perubahan suatu kejadian pada penerapan benih padi varietas ciherang terhadap faktor produksi adalah :

$$
\begin{aligned}
& P\left(x_{i}\right)=e^{\beta_{i}} \\
& P\left(x_{i}\right)=2,718^{2,875}=17,7
\end{aligned}
$$

Maka dapat dijelaskan bahwa besarnya peluang petani menerapkan benih ciherang sebagai akibat dari produksi adalah sebesar 17,7 kali. Dengan kata lain, apabila ada perbedaan produksi diantara petani sebanyak 1 kali maka akan terjadi perubahan peluang menerapkan benih padi varietas ciherang sebanyak 17,7 kali.

Hal ini sesuai dengan penelitian yang dilakukan oleh Andri Febrian Hervani (2013) berdasarkan hasil perhitungan uji statistik non parametrik atau uji chi square dengan uji hitung sebesar 4,726 lebih besar dari tabel sebesar 3,841 dengan tingkat kepercayaan 95\% menyatakan bahwa produksi petani memiliki pengaruh yang nyata terhadap pendekatan PTT padi sawah. Semakin tinggi produksi yang dihasilkan petani maka akan semakin tinggi pula sikap petani terhadap pendekatan PTT.

\section{c. Luas Lahan $\left(\mathbf{X}_{3}\right)$}

Rasio peluang sebagai rasio perubahan suatu kejadian pada penerapan benih padi varietas ciherang terhadap faktor luas lahan adalah:

$$
\begin{aligned}
& P\left(x_{i}\right)=e^{\beta_{i}} \\
& P\left(x_{i}\right)=2,718^{-14,002}=4,56
\end{aligned}
$$

Maka dapat dijelaskan bahwa besarnya peluang petani menerapkan benih ciherang sebagai akibat dari luas lahan adalah sebesar 4,56 kali. Dengan kata lain, apabila ada perbedaan luas lahan diantara petani sebanyak 1 kali maka akan terjadi perubahan peluang menerapkan benih padi varietas ciherang sebanyak 4,56 kali.

Hal ini sesuai dengan penelitian yang dilakukan oleh Sitty Muawiyah Panurat (2014) yang menyatakan bahwa koefisien regresi dari luas lahan sebesar 0.703 terlihat adanya kontribusi positif luas lahan terhadap minat dan berpengaruh sangat nyata terhadap minat petani (Pvalue $=0.002$ ). Luas lahan berpengaruh positif dan signifikan 
terhadap minat petani Desa Sendangan pada taraf yang sangat nyata 0,2 persen sehingga luas lahan sangat mempengaruhi minat petani untuk berusahatani semakin tinggi. Dimana hal ini juga sesuai dengan landasan teoritis oleh (Soekartawi, 1994 dalam Mika Jayanti, 2011) menyatakan bahwa petani yang mempunyai luas lahan yang lebih luas akan lebih mudah menerapkan inovasi dibanding petani yang berlahan sempit. Hal ini dikarenakan keefektifan dan efisiensi dalam penggunaan sarana produksi.

\section{d. Kesesuaian Lahan $\left(\mathbf{X}_{4}\right)$}

Rasio peluang sebagai rasio perubahan suatu kejadian pada penerapan benih padi varietas ciherang terhadap faktor kesesuaian lahan adalah:

$$
\begin{aligned}
& P\left(x_{i}\right)=e^{\beta_{i}} \\
& P\left(x_{i}\right)=2,718^{-0,088}=0,91
\end{aligned}
$$

Maka dapat dijelaskan bahwa besarnya peluang petani menerapkan benih ciherang sebagai akibat dari kesesuaian lahan adalah sebesar 0,91 kali.

Hal ini sesuai dengan penelitian yang dilakukan Sri Kuning Retno Dewandini (2010) yang menyatakan bahwa bahwa tingkat kesesuaian potensi lahan berada pada kategori sedang yaitu 57,5 persen atau 23 orang. Hal disebabkan karena ada daerah yang jika musim kemarau sulit mendapat air. Dilihat dari keadaan wilayah Kecamatan Minggir, air tersedia cukup melimpah akan tetapi saluran irigasi untuk daerah bagian selatan kurang memadai. Saluran air terpusat di daerah utara saja, sehingga daerah tersebut tidak pernah mengalami kekeringan bahkan air selalu tersedia meskipun musim kemarau. Adanya tingkat kesesuaian potensi lahan ini akan mempermudah petani dalam melakukan usahatani, lahan yang telah sesuai dan air yang tersedia akan mendorong petani untuk melakukan budidaya. Dimana hal ini juga sesuai dengan landasan teorits oleh (Djaenuddin dkk, 2000 dalam suyoko, 2008) menyatakan bahwa kesesuaian lahan dilihat antara sifat fisik lingkungan dari suatu wilayah dengan persyaratan penggunaan atau komoditas yang dievaluasi memberikan gambaran atau informasi bahwa lahan tersebut potensial dikembangkan untuk komoditas tersebut

\section{SIMPULAN}

Berdasarkan uraian pada pembahasan dari hasil penelitian maka dapat disimpulkan bahwa 1) Faktor selera petani, produksi, luas lahan dan kesesuaian lahan memiliki kecenderungan berpengaruh terhadap penerapan benih padi varietas ciherang. 2) Faktor variabel independen yang dimasukkan kedalam model memberikan dugaan yang sangat signifikan terhadap penerapan benih padi varietas ciherang. 3) Variabel selera petani, produksi, luas lahan dan kesesuaian lahan berpengaruh nyata terhadap tinggi rendahnya peluang petani dalam melakukan penerapan benih padi varietas ciherang.

\section{DAFTAR PUSTAKA}

Fahmi, David. 2008. Analisis Sikap Dan Kepuasan Petani Padi Varietas Unggul Di Kabupaten Kediri Jawa Timur. Skripsi Program Studi Agribisnis. Institut Pertanian Bogor. Bogor

Febrian, Andri. 2013. Faktor-Faktor yang Mempengaruhi Sikap Petani Terhadap Pendekatan PTT Padi Sawah di Kecamatan Pengabuan Kabupaten Tanjung Jabung Barat. Universitas Jambi. Jambi

Gujarati, D. 2003. Ekonometrika Dasar Dan Aplikasinya. Alih Bahasa Sumarno Zain. Penerbit Erlangga. Jakarta

Gujarati, D. 2006. Dasar-Dasar Ekonometrika. Erlangga, Jakarta.

Muawiyah, Sitty. 2014. Faktor-Faktor Yang Mempengaruhi Minat Petani Berusahatani Padi Di Desa Sendongan Kecamatan Kakas. Jurnal Penelitian Sosial Ekonomi. Fakultas Pertanian Universitas Sam Ratulangi Manado. Manado

Jayanti, Mika. 2011. Faktor-Faktor Yang Mempengaruhi Keputusan Petani Padi Sawah Menggunakan Benih Menurut Sumber Benih. Skripsi Program Studi Agribisnis. Fakultas Pertanian Universitas Sumatera Utara. Medan.

Kuning, Sri. 2010. Motivasi Petani Dalam Budidaya Tanaman Mendong (Fimbristylis globulosa) di Kecamatan Minggir Kabupaten Sleman. Jurnal Penelitian Penyuluhan dan Komunikasi Pertanian. Fakultas Pertanian Universitas Sebelas Maret. Surakarta

Suprapto, Edi. 2010. Analisis Faktor-Faktor Yang Mempengaruhi Usahtani Padi Organik Di Kabupaten Sragen. Fakultas Ekonomi Universitas Sebelas Maret Program Pascasarjana Magister Ekonomi Dan Studi Pembangunan. Surakarta.

Suyoko. 2008. Kesesuaian Lahan Kering Untuk Tanaman Wortel (Daucus Carota L.) DanBawang Merah (Allium Oscolonium L.) Di Sub Das Samin Kabupaten Karanganyar. Fakultas Pertanian. Universitas Sebelas Maret. Surakarta

Riduwan. 2009. Aplikasi Statistika dan Metode Penelitian. Dewa Ruci. Bandung 